scribed in Nature, 176, 490 (1955). Dr. Sutton has been associated with the Imperial College throughout his career as undergraduate, postgraduate research student, lecturer and reader-with a non-academic interruption by service in the Royal Electrical and Mechanical Engineers separating the first two stages. His early research work, done in collaboration with Dr. Janet Watson (Mrs. Sutton), dealt with the structural, metamorphic and plutonic history of the most ancient rocks, first of the Lewisian of the Scottish Highlands and then of the basement of East Africa. During the past decade, Dr. Sutton has built up at the Imperial College a research school concerned with the investigation in great detail of the structural history of the Moine Series of the Northern Highlands. Under his leadership, the complex history of this famous group of rocks has been patiently unravelled by meticulous field-work over considerable areas east of the Moine Thrust, and a firm foundation has been laid for a complete structural synthesis of Britain's most extensive formation. Agreeable to the definition of geology as earth-history, this work is marked by an appreciation of the importance of the timing of events in the production of crystalline schists. Under Dr. Sutton's direction in the field and the laboratory, a continued development of fundamental research in the metamorphic and plutonic rocks can confidently be expected at the Imperial College.

\section{Seals and Nets}

IN its last annual report the Nature Conservancy reluctantly accepted the desirability of experimenting in strictly limited measures of control of the Farne Island grey seal population and recommended, as an experimental and interim measure, that further increases in the grey seal should be limited by an annual cull of 300 calves, if authorized by the Minister of Agriculture, Fisheries and Food by Order under the Grey Seals Protection Act, 1932. It also recommended continuation of research and observations on seals as at present and a new attempt, sponsored by the Scottish Home Department, to discover means of protecting nets against seals. Such an Order was laid before the House of Commons on July 10 and on July 28 a motion against the Order was made by Mr. A. Blenkinsop, who, in asking what the Government was doing to encourage further research into the problem and to strengthen nets, alleged that it had refused a grant to the Nature Conservancy to enable it to carry out this research work more effectively. Widely varying views were expressed in the debate, in which the risk of exterminating the grey seal, as had happened on the north Cornish coast, was recognized by supporters and opponents of the Order. The motion was withdrawn in view of the explanation by Mr. J. B. Godber, Joint Parliamentary Secretary to the Ministry of Agriculture, Fisheries and Food, that no final decision had been taken as to the merits of culling as a means of controls and his undertaking to look into the possibility of assistance to further research work.

\section{Committee on Grants to Students}

ThE Ministry of Education and the Scottish Education Department announce that the Committee on Grants to Students set up recently under the chairmanship of Sir Colin Anderson (see Nature, $182,20 ; 1958)$ is now ready to receive written evidence. Any interested persons or bodies are invited to submit a memorandum to the secretaries (for England and Wales, Mr. D. Neylan, Ministry of Education, 14 Cornwall Terrace, London, N.W.1, and for Scotland, Mr. G. A. T. Hanks, Scottish Education Department, St. Andrew's House, Edinburgh 1), if possible not later than November 30 . The terms of reference of the Committee are: "to consider the present system of awards from public funds to students attending first degree courses at universities and comparable courses at other institutions and to make recommendations". Among the questions which the Committee will be considering are the kinds of awards to be made from public funds, the method of selecting students for such awards and the principle of the hardship test required by the law as it now stands.

\section{Adventures in Science}

THE Smithsonian Institution has just published a new popular science booklet for young people, designed to show "that science can be exciting and that science can be fun". Entitled "Adventures in Science at the Smithsonian", the illustrated 24-page booklet tells about a few of the scientific milestones that have marked the progress of civilization and shows part of the outstanding role that the Smithsonian has played in the advancement of science since its founding in 1846. Planned to appeal primarily to children in junior schools, "Adventures in Science" not only presents information about many different sciences in simple, easy-to-read form but is also extensively illustrated in colour with objects from the Smithsonian's collections. The booklet can be read in two ways-from front cover to back, or from back cover to front. The natural sciences occupy the first half of the publication, while the physical sciences and engineering occupy the second half. If the reader begins at the back page, he starts in the present-." Tracking Earth Satellites", - and reads back into time. If he starts at the front, he journeys from "The Dinosaur Age" to the present. The authors, E. John Long and George Weiner, have simplified the often prolix terminology of science. For example, the subject of anthropology is covered in the section entitled "Searching for Cave Men", and astronautics, or rocketry, is discussed in "Into Space". The price for single copies is 25 cents.

\section{Laws in Social Science}

ONE of the main points made by Sir Alexander Carr-Saunders in his recent Eleanor Rathbone Memorial Lecture at the University of Liverpool ("Natural Science and Social Science". Pp. iv + 15. Liverpool University Press, 1958. 3s.) is that, despite many attempts by social scientists to discover laws and law-like correlations by using the procedures of the natural sciences, "nothing remotely resembling a law of the natural sciences has yet been produced". Carr-Saunders agrees with J. S. Mill who, in his "System of Logic", subjected the possibility of using natural science procedures in the social sciences to exhaustive analysis. His conclusions were that, because of what Mill called "the complication of causes" and of the impossibility of insulating the variables concerned from the large influences of extraneous factors, no laws can be established in the social sciences in this way. It is not surprising that none has been discovered. "If such laws could be discovered they would appertain rather to a world of ants than to a world of men." 